\title{
Seafloor facies related to upward methane flux within a Giant Pockmark of the Lower Congo Basin
}

\author{
A. Gay ${ }^{a^{*}}$, M. Lopez ${ }^{b}$, H. Ondreas ${ }^{\text {c }}$, J.-L. Charlou ${ }^{c}$, G. Sermondadaz ${ }^{d}$ and P. Cochonat ${ }^{\text {c }}$ \\ ${ }^{a}$ National Oceanography Centre of Southampton (NOCS), Empress Dock, SO14 3ZH, Southampton, UK \\ bUniversité Montpellier 2, Laboratoire de Dynamique de la Lithosphère, CC60, Bât 22, place E. Bataillon, 34095 \\ Montpellier cedex 05, France \\ 'IFREMER, Département Géosciences Marines, 29280 Plouzané, France \\ ${ }^{\mathrm{d}}$ TOTAL, 64018 Pau Cedex, France \\ *: Corresponding author : Tel.: +44 2380686614. ayg@noc.soton.ac.uk
}

\begin{abstract}
The origin of the cold fluid venting from a Giant Pockmark within the Lower Congo Basin has been elucidated based upon results of precise mapping, submersible dives, gravity coring and isotopic analyses realized under a TOTAL-IFREMER cooperative project (ZAIANGO and BIOZAIRE projects).

During four dives of the IFREMER ROV-Victor 6000, the bottom was filmed, hard and soft samples were lifted from the sediment, and water samples were collected with a CTD-rosette system. The detailed dip map shows that the $800 \mathrm{~m}$ wide Giant Pockmark is a composite feature due to the coalescence of multiple $100 \mathrm{~m}$ wide depressions that displays a broad range of biological, mineralogical and chemical features on the seafloor, leading to a seafloor anomaly recorded on the multibeam imagery. Methane-rich fluids migrating through the sedimentary column from a buried palaeochannel clearly react with the sulphate-rich circulating sea water to produce hydrogen sulphide and bicarbonate ions. This situation leads to a concentrical arrangement of the sedimentary facies, with methane-related features in the centre and sulphide-related features at the periphery. This organization is correlated with high levels of methane (up to $20 \mu \mathrm{mol} / \mathrm{l}$ ) measured in the centre of the Giant Pockmark, responsible for the crystallization of gas hydrates at the bottom.

In this model, the concentrical organization of mineralogical and biological features reflects a geochemical partitioning related to the peripheral progressive mixing of the methane flux.
\end{abstract}

Keywords: pockmark; fluid migration; seafloor facies; chemosynthesis; hydrates; palaeochannel; ZAIANGO; BIOZAIRE 
A.Gay et al - Seafloor features related to methane flux within a pockmark

\section{Introduction}

Pockmarks have been widely reported during offshore hydrocarbon exploration and scientific surveys at water depths ranging from $30 \mathrm{~m}$ to over $3000 \mathrm{~m}$ (for a detailed review see Baraza et al., 1999; Solheim et al., 1993; Hovland et al., 1988; Whiticar et al., 1981; Werner, 1978; Josenhans et al., 1978; King et al., 1970). They generally appear in unconsolidated fine-grained sediments as cone-shaped circular or elliptical depressions ranging from a few meters to $300 \mathrm{~m}$ or more in diameter and from $1 \mathrm{~m}$ to $80 \mathrm{~m}$ in depth. The crater-like nature of pockmarks suggests the erosional power of fluid venting, commonly related to an overpressured buried reservoir of biogenic gases, thermogenic gases or oil, interstitial water, or a combination of the three. Because of the nature of fluids expelled, pockmarks may represent open-windows above the petroleum system and could be valuable indicators for deeper reservoir strategy (Heggland, 1998).

The geology, biology and mineralogy of modern submarine cold seeps have been widely described on continental rise since 1980 (Diaz del Rio et al., 2003; Sibuet et al., 1998; Dando et al., 1991; Kulm et al., 1986; MacDonald et al., 1989). Subsequent explorations increased the known geographic range of similar communities and documented their occurrence at cold seeps as well as hydrothermal vents (Laubier et al., 1986; Kennicutt II et al., 1985; Suess et al., 1985; Paull et al., 1984). Bivalves, gastropods, vestimentiferans, bacterial mats, sea anemones, galatheia crabs and shrimps live together forming benthic communities within fluid seeps (Vogt et al., 1999a). These systems are fed by cold nutrient-rich fluids primarily containing methane $\left(\mathrm{CH}_{4}\right)$ and hydrogen sulphide $\left(\mathrm{H}_{2} \mathrm{~S}\right)$. The $\mathrm{CH}_{4}$-charged pore fluids are being expelled in cold seeps from the sediments and authigenic carbonates are precipitated as crusts, pavements or concretions at the sediment/water interface ( Aloisi et al., 2002; Greinert et al., 2002; Olu et al., 1997; Von Rad et al., 1996; Jorgensen, 1992; Ritger et al., 1987; Hovland et al., 1985). Such methane-derived, seep-related carbonate buildups are typical byproducts of microbial chemosynthesis and have been termed "chemoherms" by Roberts and Aharon (1994). During the past 20 years, descriptions of vents and associated seep communities have been based primarily upon interpretations of still and video photographs, which have provided information concerning spatial distribution and temporal variation of abundance (Milkov et al., 1999; Jollivet et al., 1990; MacDonald et al., 1989; Hecker, 1985). Despite the geographic and taxonomic diversity of the chemosynthetic communities described, they share several characteristics, such as the large depth range of occurrence, the density of individuals, the diversity of taxonomic assemblages, the apparent heterogeneous seafloor distribution, the abrupt transition between the endemic communities and the normal surrounding environment (Sibuet et al., 1998; Olu et al., 1996; MacDonald et al., 1989; Brooks et al., 1987; Kennicutt II et al., 1985). However, the investigations of the distribution have been limited to the observation that different patterns within vents are attributed to supposed spatial and/or temporal variations in the supply of sulphides and methane (MacDonald et al., 1989) or other hydrocarbons (Wenger et al., 2002).

We discuss here the relationship between the inside morphology of a Giant Pockmark located in the Lower Congo Basin, the seafloor facies (biology and carbonate buildup), the EM-12 multi-beam anomalies (i.e. the reflectivity), the occurrence of gas hydrate and the concentration of dissolved methane in bottom water. Four "seeps" facies were identified that are concentrically arranged: the methanedependant assemblage is located in the centre of the depression although the sulphide-dependant assemblage is located on the outer border. This organization could be a useful means for assessing the intensity of upward fluid migration and the dynamic of such seepages. 


\section{Geological settings}

The West African passive margin was initiated during the opening of the South Atlantic Ocean at Early Cretaceous (130 My) ( Marton et al., 2000; Jansen et al., 1984). Subsequent to large accumulations of evaporites (up to $1000 \mathrm{~m}$ ) during the midAptian time (Valle et al., 2001), the post-rift stratigraphy is characterized by two superposed seismic architectures that reflect a major change in ocean circulation and climate (Séranne et al., 1992): 1) from Late Cretaceous to early Oligocene time, an aggradational carbonate/siliciclastic ramp develops (greenhouse period) and 2) from early Oligocene to Present time, the sedimentation is dominated by the progradation of a terrigenous wedge (Icehouse period) (Séranne, 1999). During the Icehouse period, the high-frequency alternating climatic conditions have triggered deep incision and erosion and large amounts of terrigenous material have led to the formation of a 2000$3000 \mathrm{~m}$-thick progradational wedge. In particular, the increased terrigenous input to the margin is responsible for the formation of the large turbiditic fan off Congo and Angola slope (Fig. 1) directly fed by the Zaire River (Droz et al., 1996; Uchupi, 1992; Brice et al., 1982). It extends from the Zaire River estuary to the lower fan, down to $5000 \mathrm{~m}$ water depth.

Figure 1: Bathymetric map of the Congo-Angola Basin issued from the EM-12 multibeam bathymetry acquired during the ZAIANGO project (1998-2000). The study area (grey-shaded rectangle) is located accros the present-day Zaire channel, at a water depth between 3000 and $3700 \mathrm{~m}$. The investigated Giant Pockmark is on the northern flank of the Zaire channel, at a water depth of about $3200 \mathrm{~m}$. The three sites of the Leg ODP 175 in this zone are reported.

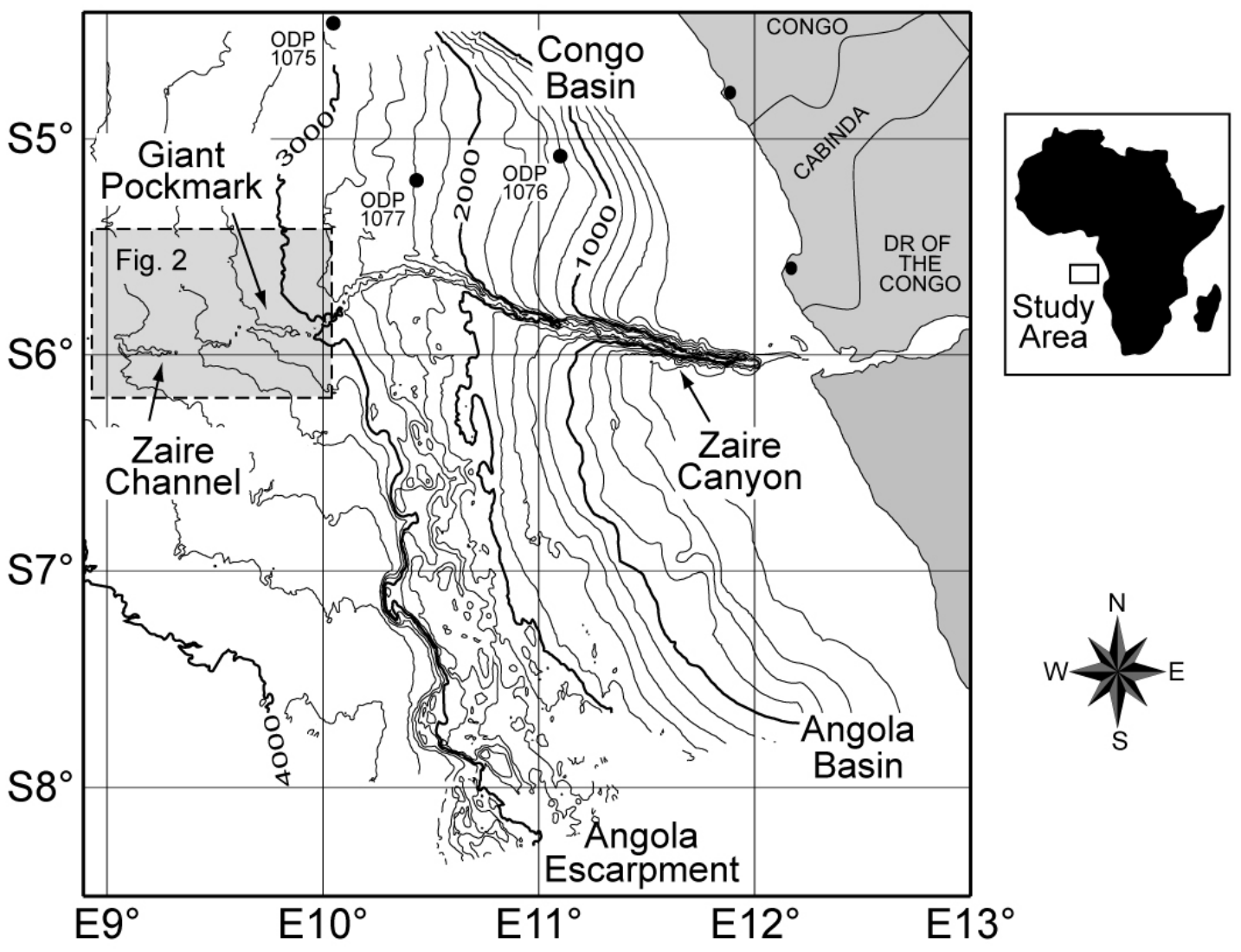


A.Gay et al - Seafloor features related to methane flux within a pockmark

\section{Sampling and methods}

Both chemosynthetic cold seep communities and authigenic carbonate may cause higher acoustic impedance and roughness than occur in the surrounding seafloor. Seafloor mapping systems may therefore be able to identify the distribution of potential seeps using acoustic backscatter data (Orange et al., 2002). Numerous patches are imaged on both bathymetric maps and low-grazing angle backscatter systems in the Lower Congo Basin. We focus on an outstanding Giant Pockmark, 800 $\mathrm{m}$ wide, which lies on the north side of the present day Zaire channel, at about $3150 \mathrm{~m}$ water depth (Fig. 2). In this area, only fine sediments not confined to the Zaire channel were deposited, perhaps from riverine plumes and contour currents, through sedimentation by aggregates and fecal pellets (Cooper, 1999; Giraudeau et al., 1998) and mixed with hemipelagic sediments on the continental slope.

Figure 2: EM-12 multi-beam mosaic in the area of the Zaire Canyon. The patch on the North right flank of the channel corresponds to the investigated Giant Pockmark. The Core C-1 has been recovered outside the Giant Pockmark, $1 \mathrm{~km}$ to the north.

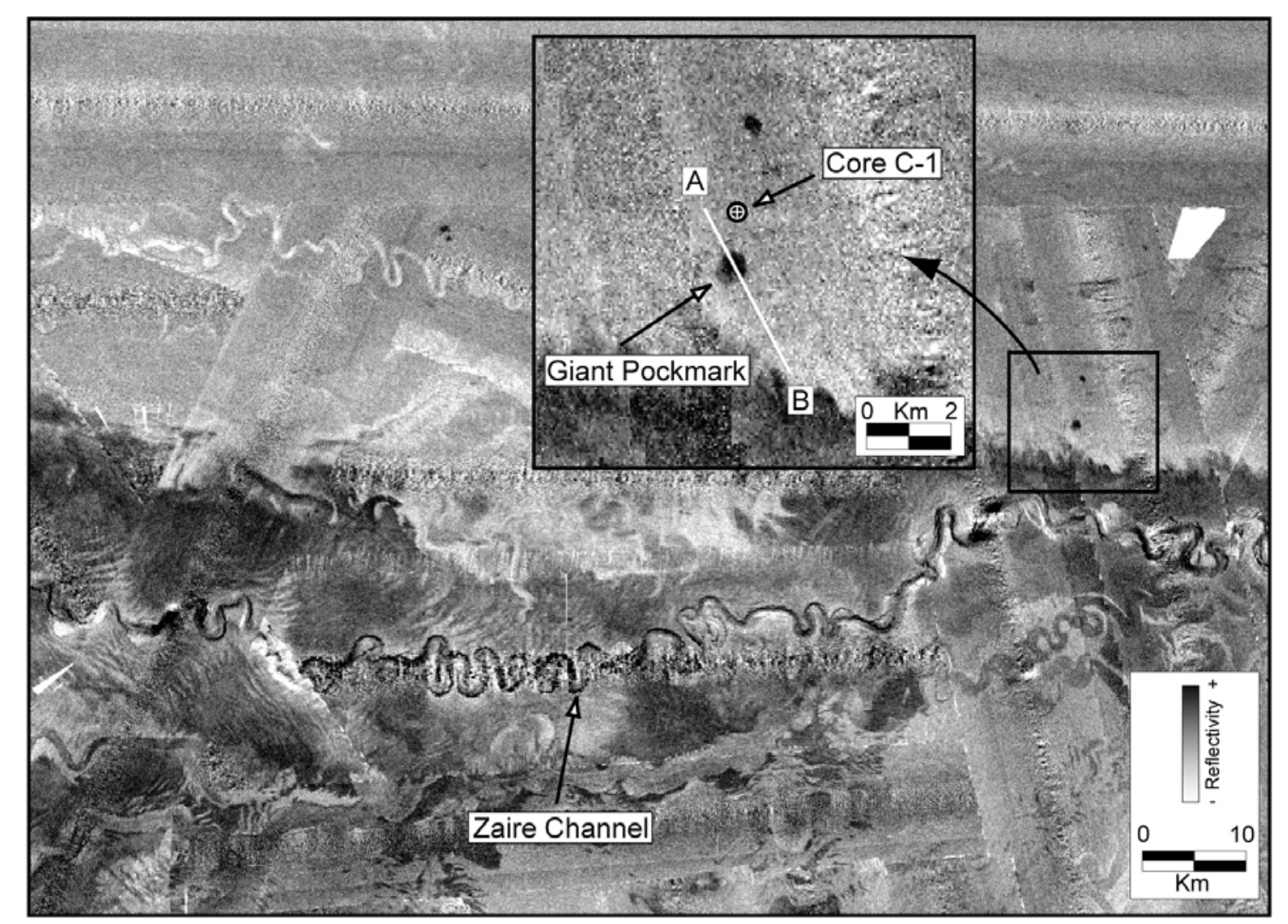

The Giant Pockmark was discovered during the ZAIANGO Project (19982000), primarily based on bathymetric-reflectivity maps and 2D High-Resolution seismic profiles to better understand the Quaternary history of the Zaire fan (Savoye et al., 2000). The Giant Pockmark and its surroundings were explored in detail during four dives of the IFREMER ROV-Victor 6000 during the ZAIROV-2 and BIOZAIRE surveys focused on cold seeps. Additional data from the Leg ODP175 on the West African Margin provided useful information on stratigraphy, sedimentation rates and mechanical properties of sediments (Wefer et al., 1998). 
During the ZAIROV-2 survey, the two first exploratory dives consisted of a series of long transects, during which the submersible attempted to cover a maximum surface of the Giant Pockmark (Fig. 3). During the BIOZAIRE survey, the two last dives focused on some particular biochemical and biological features near the centre of the depression (Fig. 3). During the dives, hard samples were lifted from the sediment using the manipulator, soft samples were cored with mini-tubes $(40 \mathrm{~cm})$ and water samples were collected with a rosette system of 19 bottles. Chemical and geochemical analyses of methane concentrations and hydrates were conducted at IFREMER (for details see Charlou et al., 2004). Standard piston cores (<14 m long) were recovered in the area of the Giant Pockmark: the core C-1 is outside the depression, $1 \mathrm{~km}$ to North (see Fig. 2 for location), the core C-2 is in the center and the core C-3 is on the eastern border of the depression (see Fig. 3 for location). Massive gas hydrates crystals were found (Charlou et al., 2004): 1) outcropping on the seabed and 2) at $6 \mathrm{~m}$ below seafloor in the core C-3. The position of submersible was calculated with a DGPS and the navigation data were wiped free of aberrant points. The position of transects, cores and bathymetric/reflectivity maps were then plotted on a geo-referenced Arc-View based platform developed by IFREMER, which allows a replaying of the video records. The submersible was equipped with sonar enabling the calculation of the micro-bathymetry within the Giant Pockmark. The data height and dumping were added along transects and interpolated by method of the krigging in the Arc-View based software (Ondreas et al., in press).

Figure 3: Isochronal map of the Giant Pockmark issued from EM-12 multi-beam bathymetric data. White lines represent the bottom transects of the ROV-Victor 6000. Two piston cores were recovered inside the depression, one in the centre (C-2) and one near the east border (C-3). Massive hydrates have been found in the core $\mathrm{C}-3$ and outcropping at the seabed in the centre of the Giant Pockmark.

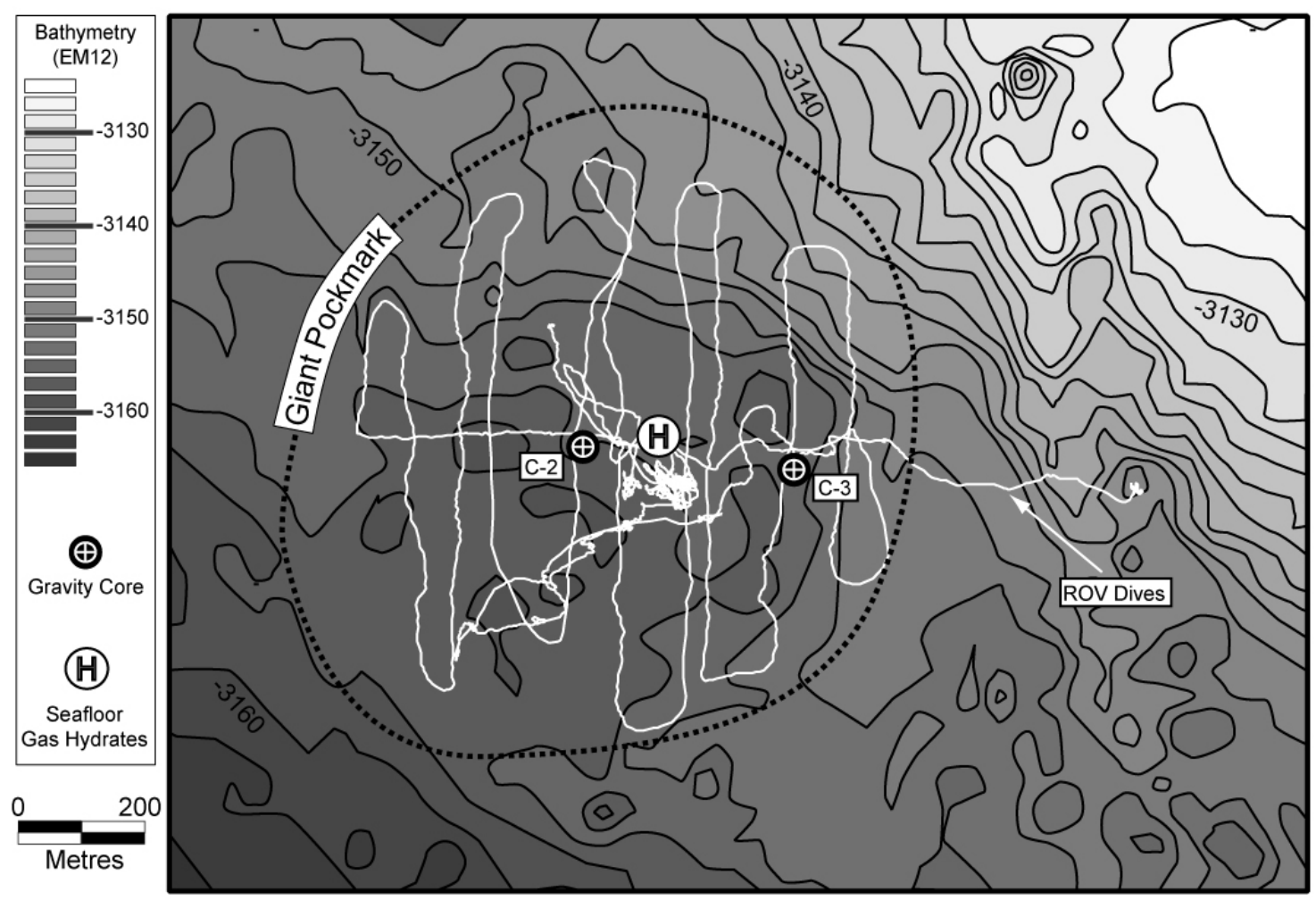


A.Gay et al - Seafloor features related to methane flux within a pockmark

\section{The origin of fluids expelled from the Giant Pockmark}

Pockmarks generally concentrate in fields extending over several square kilometers where they often appear as isolated patches named single pockmarks or "eyed pockmarks" (Hovland et al., 1988). In some cases, they have been identified along straight or circular lines correlated with glaciomarine tills (Josenhans et al., 1978; Whiticar and Werner, 1981; Kelley et al., 1994) or suggesting a structural control for fluid flow (Shaw et al., 1997; Taylor et al., 2000). In particular, structural surfaces along bedrock (Shaw et al., 1997); salt diapirs (Taylor et al., 2000); and faults and faulted anticlines (Boe et al., 1998; Soter, 1999; Vogt et al., 1999b; Eichhubl et al., 2000) create pathways for fluid migration. These observations suggest that discontinuities or unconformities are much more effective for fluid migration than a simple seepage through the sedimentary column (Abrams, 1992; Brown, 2000) and are responsible for pockmarks development (Abrams, 1996; Orange et al., 2002). Many authors attempted to establish a link on seismic sections between seafloor pockmarks and buried anomalies such as seismic chimneys (Heggland, 1998) and acoustically "blanked" layers, which are interpreted as gas accumulations (Yun et al., 1999) or gas-charged sediments (Hovland, 1984; Hempel et al., 1994). On the slope of the Lower Congo Basin, pockmarks are not randomly distributed, but always associated with fault zones, salt diapirs or a BSR (Gay et al., 2003), which is a strong evidence for the presence of gas hydrates.

The seismic profile AB (Fig. 4) crosses the Giant Pockmark from NW to SE. The pockmark is connected to an underlying acoustic anomaly, $200 \mathrm{~m}$ wide, which is characterized by acoustic turbidity and a fadeout of the reflectors. On both sides of the anomaly the bright reflectors are disrupted and shift upward, indicating a seismic reflection phase reversal. This kind of acoustic anomaly is now interpreted as a seismic chimney (Heggland, 1998) and is indicative of an ascending movement of fluids from deeper reservoirs. The high resolution seismic profiles issued from the ZAIANGO project allows to determine the connection between the chimney and the reservoir. At about 400 msTWT below seafloor, the seismic chimney branches on an ancient buried channel-levee system. The base of the chimney is located on the northern edge of the channel fill where it seems to take root because of the lack of any deeper sound-speed anomaly. The seismic profile shows a buried palaeo-pockmark at about 100 msTWT below seafloor. The underlying chimney develops on the southern flank of the channel fill at the channel-levee interface. Due to the high sealing capacity of hemipelagic sediments in the Lower Congo Basin, this buried palaeochannel may be turned off at the present day (Gay et al., 2003). However, the enhanced reflections over the buried palaeo-pockmark may suggest that fluids are going to migrate through the overlying sedimentary cover. 
Figure 4: Seismic profile AB (see Fig. 1 for location). The Giant Pockmark seems to take root at the channel-levee interface of a shallow buried palaeochannel. A sealed pockmark with its underlying chimney is visible on the south flank of the buried palaeochannel. The Giant Pockmark may be fuelled by a relict of biogenic fluid entrapped within the channel (Gay et al., 2003). This is confirmed by isotopic analyses on hydrates recovered in the core C-3 (Charlou et al., 2004).

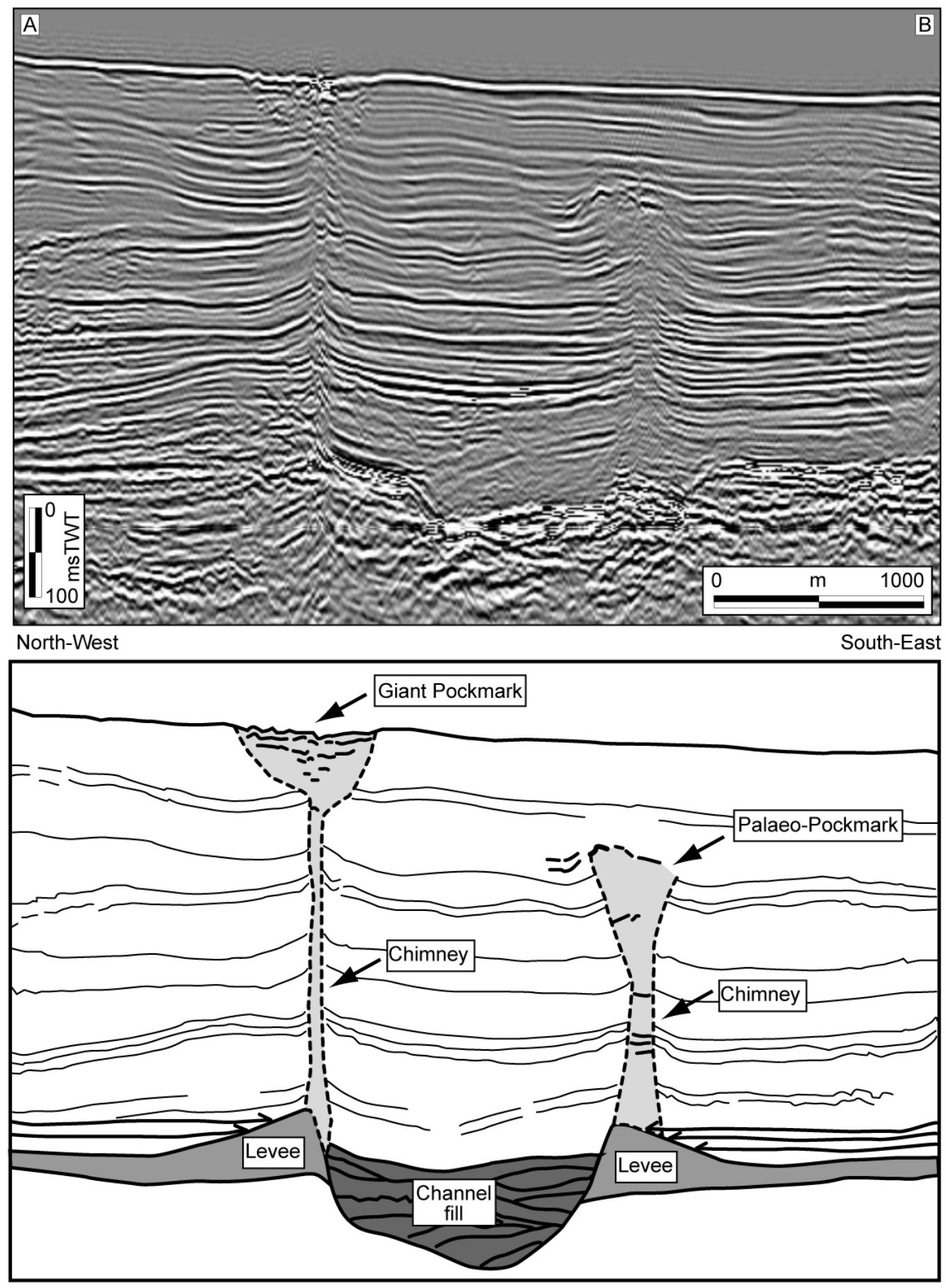


The shallow burial of the palaeochannel ( $<300 \mathrm{mbsf}$ ) suggests a biogenic origin for the fluids they are escaping from. This is confirmed by isotopic analyses conducted on hydrates from the core C-3 (Charlou et al., 2004). The results have shown $\delta^{13} \mathrm{C}$ values of the methane lighter than $-69 \%$ o $(P D B)$ and a ratio $C 1 /(C 2+C 3)$ greater than 1000 , highly indicative of a biogenic origin.

\section{Seafloor reflectivity related to seismic facies of shallow sediments}

Pockmarks are easily imaged using side-scan sonar and multi-beam bathymetric surveys. During the ZAIANGO surveys, the slope of the Lower Congo Basin has been intensively covered by EM-12 multi-beam imagery allowing the identification of numerous pockmarks on seafloor. We particularly focused on this Giant Pockmark because it appears as a large black patch, $800 \mathrm{~m}$ wide, on the reflective map (Fig. 5). The reflectivity intensity is low at the outer border of the depression and increases toward the centre. 
Figure 5: Enlargement of the EM-12 multi-beam mosaic showing details of the Giant Pockmark. It appears as a large patch, $800 \mathrm{~m}$ wide, and the reflectivity intensity increases toward the centre of the depression. The seismic profile CD (detail of the profile $A B$ ) shows chaotic facies below the pockmark defining a Tulip-shape anomaly. These strong reflections may be related to gas accumulations, authigenic carbonate precipitation, gas hydrate or enhanced porosity contrasts.
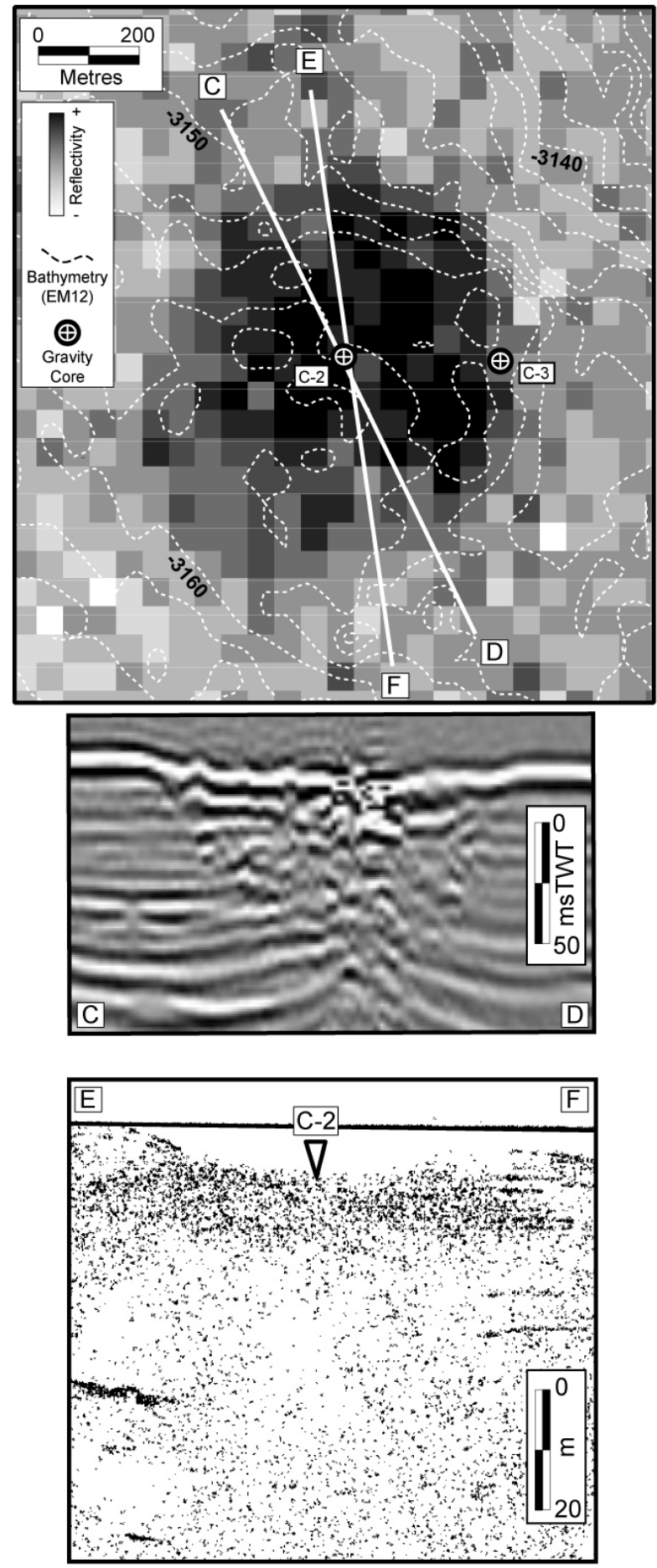
The reflection-strength seafloor anomaly issued from the multi-beam mosaic correlates well with a set of strong chaotic reflections on the seismic profile CD (enlargement of the profile $A B$ ) directly beneath the depression (Fig. 5). The width of the chaotic facies decreases with depth and connects to the seismic chimney at about 75 msTWT, defining a Tulip-shape anomaly on the seismic profile. Small-scale faults, dipping towards the centre, develop within the Tulipe-shape anomaly. Such faults may drive fluids upward, up to the seafloor. On both sides of the anomaly, the reflectors are disrupted and they shift upward. They do not correlate with chaotic reflections within the Tulip-shape anomaly, suggesting that the active fluid venting started at this level. Lateral abrupt changes in impedance values may be due to enhanced density and/or velocity contrasts, which may be related to small-scale gas accumulations caused by strong fluid expulsion (Taylor et al., 2000). However, other phenomena such as highvelocity authigenic carbonate accumulations, thin high velocity layers with elevated gas hydrate concentration, or enhanced porosity contrasts by trapped overpressured fluids may also cause high and low reflection strengths. The $3.5-\mathrm{kHz}$ seismic profile EF across the Giant Pockmark shows side echoes that overlap to form "bow-tie" structures, which could indicate the presence of a hard substratum on seafloor (Fig. 5).

\section{Fluid seep evidences within shallow sediments}

The core C- 1 was collected at the periphery of the Giant Pockmark, on its northern border, at $3144 \mathrm{~m}$ water depth (see Fig. 2 for location). This core features hemipelagic muds, typically classified as greenish grey and olive-grey diatomaceous clay with several levels of high bioturbation or pervasive burrows, broken and unbroken bivalve's shells and lamellibranchs and chondritic nodules (LeMoigne, 1999) (Fig. 6). This core reflects the nature of regional suspension setting sediments as described during the Leg ODP 175 (Wefer et al., 1998).

The core C-2 (see Fig. 3 for location) was collected at $3161 \mathrm{~m}$ water depth, near the centre of the Giant Pockmark. Sediments are composed of dark greenish nannofossil-bearing siliceous (diatoms and radiolarian) silty clay (Fig. 6). In the four upper metres, the sediments are similar to those described in the core C-1. Although bivalve's shells and lamellibranchs are common, the bioturbation is characterized by localized burrows and decreases with depth. In the seven lower metres, sediments are intensively deformed by pockets of bright greenish to sallow liquefied sediments displaying "puffs of pipe" features along the core (LeMoigne, 1999) (see photo 1 on the Fig. 6). These pockets seem to be connected to centimetre scale conduits of oxidized sediments or tubular carbonates and are interpreted as ancient markers of fluid migration (Hovland et al., 1988; Sills et al., 1992; Yuan et al., 1992). 
Figure 6: Sedimentary logs of cores C-1 (in the North) and C-2 (in the centre). The core C-1 displays the regional nature of sediments (LeMoigne, 1999). The core C-2 (in the centre of the depression) is intensively perverted by pockets of bright greenish to sallow liquefied sediments, which may be caused by fluid migration.

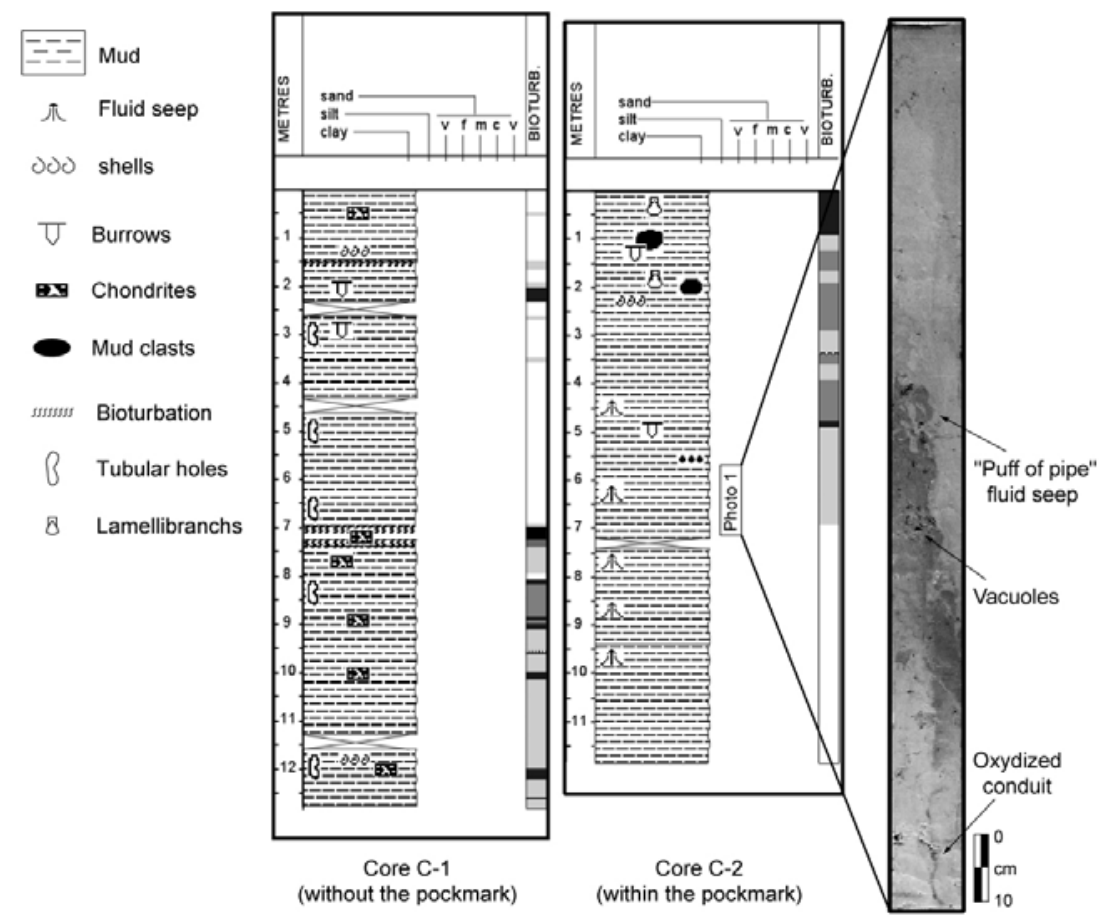

The core C-3 (see Fig. 3 for location) was collected at $3158 \mathrm{~m}$ water depth, at the eastern border of the Giant Pockmark. Sediments are very similar to the core C2 in the first $6 \mathrm{~m}$ below seafloor. Below this level no sediments were saved because of the presence of thick layers of pure methane hydrates inter-bedded with thin layers of muds.

\section{Internal morphology of the Giant Pockmark}

Most of the pockmarks in the Lower Congo Basin have a circular shape in plan view, but the largest pockmarks are often elongated in one main direction (Gay et al., 2003). This is the case here and the regional bathymetry obtained with the EM12 dual multibeam shows that the Giant Pockmark corresponds to a $800 \mathrm{~m}$ wide and $16 \mathrm{~m}$ deep depression (Fig. 7). The dip map of the Giant Pockmark (calculated from the microbathymetry) help to better define the internal morphology of the depression (Fig. 7). Detailed observations show that the Giant Pockmark is composed of the coalescence of about twenty smaller depressions. They ranged from roughly circular areas, 50 to $100 \mathrm{~m}$ wide, to curvilinear features several tens of metres. Finally, the most substantial depressions included intertwining curved features suggesting that they have apparently formed by successive episodes of fluid release or the source has moved around during time. 
Figure 7: Dip map of the Giant Pockmark calculated from the Microbathymetry obtained with the ROV-Victor 6000 (Modified after (Ondreas et al., Submitted)). Detailed observations show that the Giant Pockmark, $800 \mathrm{~m}$ wide, is composed of the coalescence of several smaller pockmarks, $100 \mathrm{~m}$ wide.

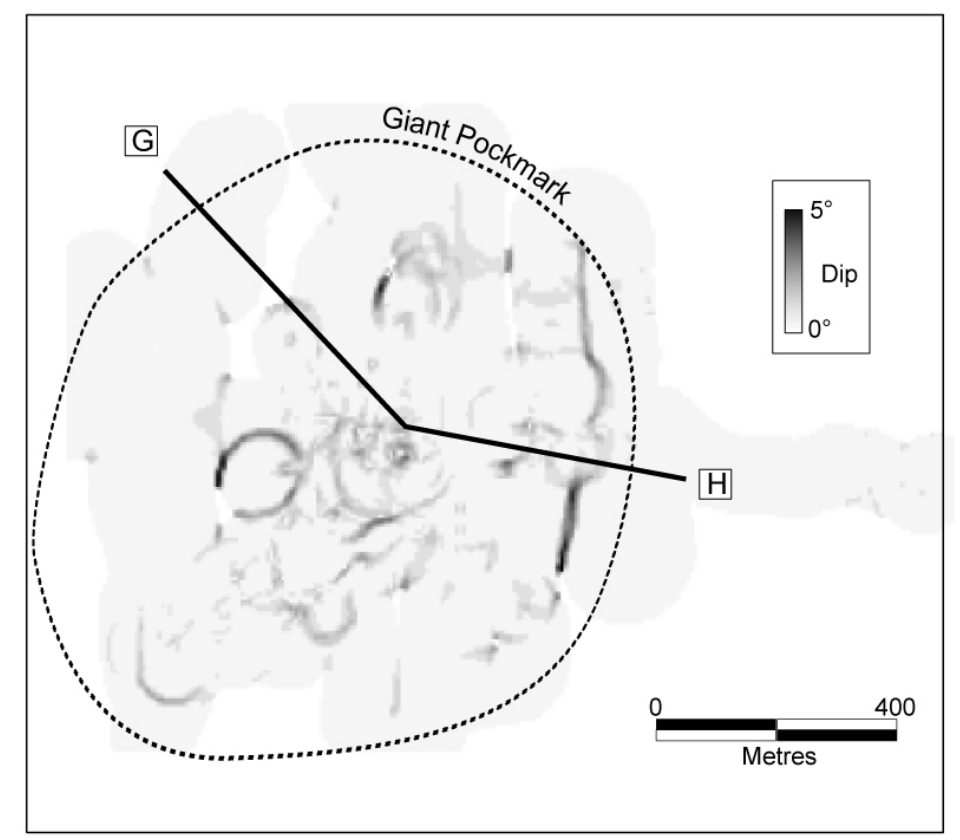

Methane concentration at the sediment-water interface

During dives, water was sampled with 19 mini-bottles, three metres above the bottom, and analysed on board by a chromatographic-purge/trap technique (Charlou et al., 1993). These analyses of near-bottom water have revealed extremely high methane $\left(\mathrm{CH}_{4}\right)$ concentrations up to 1-5 $\mu \mathrm{l} / \mathrm{l}$ within the Giant Pockmark (Charlou et al., 2004).

The maximum methane concentration $(129 \mu \mathrm{l} / \mathrm{l})$ has been measured near the centre of the Giant Pockmark. This concentration is up to 10000 times the concentration of methane in the oceanic background. The methane anomaly decreases down to $0.01 \mu \mathrm{l} / \mathrm{l}$ near the periphery of the depression, corresponding to the normal oceanic background at $3000 \mathrm{~m}$ water depth.

Complementary analyses have been conducted during the cruise. Three vertical CTD/rosette were carried out in the centre of the pockmark, $200 \mathrm{~m}$ in the West, and $1 \mathrm{~km}$ in the South-West, showing a wide plume of $\mathrm{CH}_{4}, \mathrm{Mn}, \mathrm{Fe}$ and nephelometry in a $200 \mathrm{~m}$ thick water layer above the depression (Charlou et al., 2004). This could indicate an active fluid venting in the centre of the pockmark at the present day (Charlou et al., 1993; Sassen et al., 1994; Suess et al., 1999; Sassen et al., 2001).

\section{Biological and mineralogical organization within the giant pockmark}

Based on direct observations of the bottom realized at IFREMER (Olu-Le Roy et al., 2003) (Profile GH, see Fig. 7 for location), we have identified five seafloor facies (A, B, C, D, E) from the periphery to the centre of the main depression (Fig. 8). 
Fluid expulsion out of the seafloor can lead to an increase in biomass, which may be further enhanced by the hard bottom substrate provided by authigenic carbonates.

Figure 8: Synthetic shallow profile EF (see Fig. 6 for location) across the Giant Pockmark. This profile compiles data from the bottom reflectivity intensity, the methane concentrations of bottom waters and the mineralogical-biological facies (A to E) described in this study. The high level of disturbance in the centre of the Giant Pockmark could be due to stacked carbonate domes and large areas of living and dead fauna.

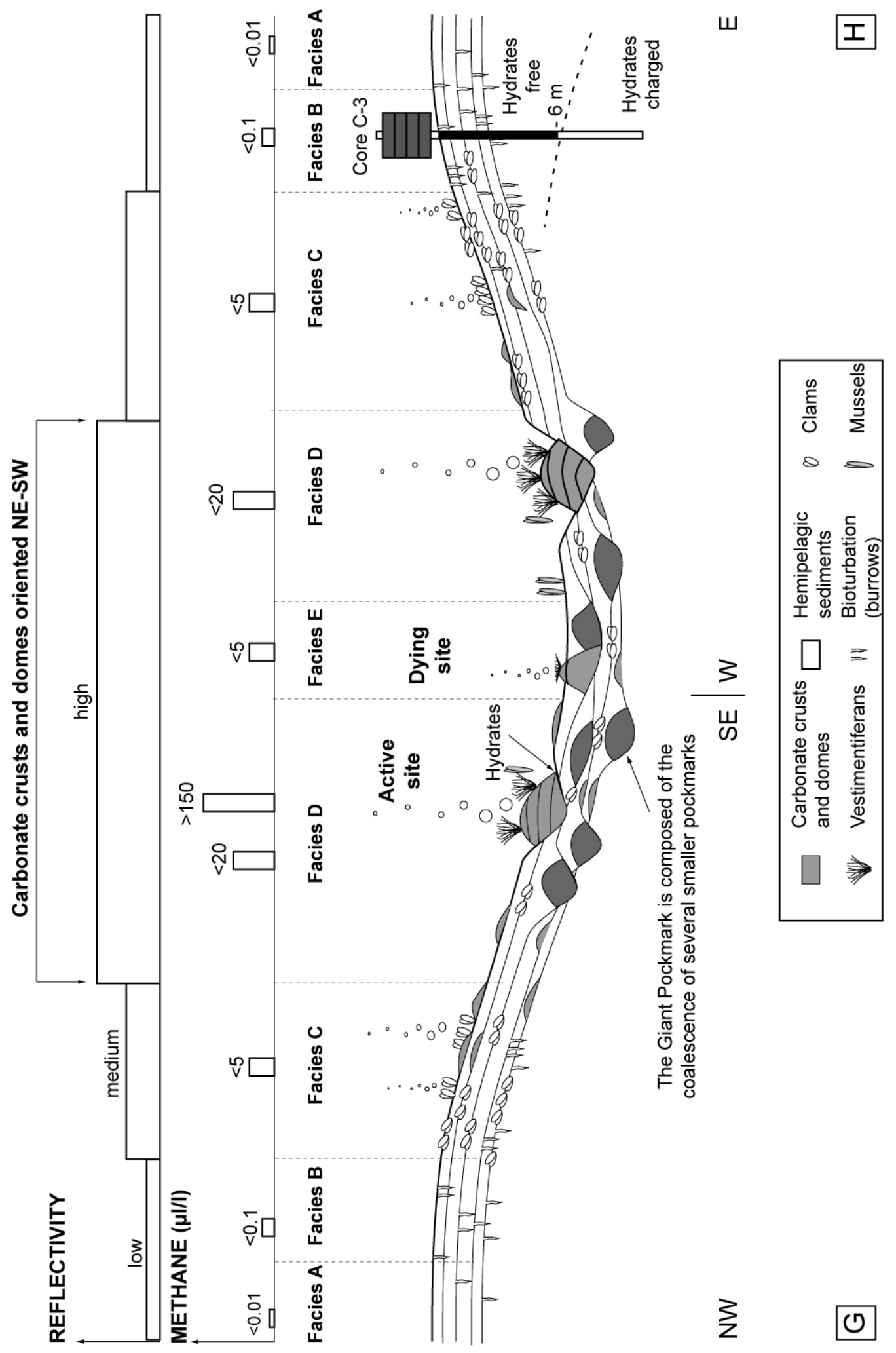


- Facies A: The biologically depauperate periphery of the depression corresponds to the regional seafloor. The olive-grey hemipelagic sediments are moderately bioturbated and the concentration of dissolved methane is very low $(<0.01$ $\mu \mathrm{l} / \mathrm{l})$, corresponding to the oceanic background.

- Facies B: This facies is located at the outer border of the depression. The bottom in this region is mostly bioturbated, showing extensive ichnotraces and burrows, shallow depressions and small mud mounds ( $<30 \mathrm{~cm}$ high), very few organisms were seen or photographed. Generally, the colour of the sediment changes to a slate-grey toward the top of the mud mounds. In this peripheral zone, the concentration of dissolved methane is generally lower than $0.1 \mu \mathrm{l} / \mathrm{l}$.

- Facies C: This facies, located within the depression of the Giant Pockmark, is characterized by patches of black reduced sediments partly covered by whitish bacterial mat that are often populated by wide communities of clams of the genus Vesicomyidae (Olu-Le Roy et al., 2003). The bacteria associated with living clams indicate areas of active sulphide seeping (MacDonald et al., 1990), and X-ray diffraction analysis of black reduced sediments have shown some evidences of pyrite precipitates (Ondreas et al., In Press). The medium concentration of dissolved methane $\left(1<\mathrm{CH}_{4}<5 \mu \mathrm{Mol} / \mathrm{l}\right)$ above living clams may indicate a slow seepage of fluids at the outer border of the depression.

- Facies D: This facies is mainly located in the centre of the Giant Pockmark. It is populated by lush benthos life (sea anemones, sea pens, sponges, shrimp, octopus, small sharks, eel-like fish, holoturians, sea urchin, gastropods) and endemic methane-dependant life (Vestimentiferan tube worms and mussels of the genus Mytilidae) (Olu-Le Roy et al., 2003). They live around large mounds, 20-50 m in diameter and $4 \mathrm{~m}$ high, which are composed of stacked authigenic carbonate crusts, pitted by worms or bivalve boring. It means that the immediate surrounding of the mounds is now in the process of being exhumed, probably due to the erosion by fluid escape along the flanks. These carbonates mounds form a chaotic indurated relief of domes and valleys in each $100 \mathrm{~m}$ wide individual pockmark. They exhibit a broad range in mineral composition, alternating Mg-rich calcite and aragonite (Ondreas et al., In Press). The centre of the Giant Pockmark is characterized by $20 \mu \mathrm{M} / \mathrm{l}$ of dissolved methane into the bottom water, indicating an active fluid venting dominated by methane.

- Facies E: This facies is mainly located in the centre of the Giant Pockmark. It is characterized by areas of pavements or domes without endemic benthos life and low concentrations of dissolved methane $(<20 \mu \mathrm{l} / \mathrm{l})$. These non-active areas could be considered as "fossil" sites and suggest that methane fluxes may have been higher than at present (Stakes et al., 1999), representing self-sealing seeps locations (Hovland, 2002).

\section{Discussion}

\section{A model of seafloor features related to up-flow intensity of methane}

Microbes form methane through two predominant pathways (Claypool et al., 1974). Acetate fermentation dominates in freshwater systems (Whiticar et al., 1986), whereas $\mathrm{CO}_{2}$ reduction dominates in marine systems (Fenchel et al., 1979). In marine sediments, methane generated at greater depth and migrating upward interacts with sulphate at the base of the sulphate reduction zone and the top of the methanogenic zone (Martens et al., 1974) (Equ. 1).

$$
\mathrm{SO}_{4}^{2-}+\mathrm{CH}_{4} \rightarrow \mathrm{HS}^{-}+\mathrm{HCO}_{3}^{-}+\mathrm{H}_{2} \mathrm{O}
$$


In anoxic environments this Sulphate-Methane Interface (SMI) is generally found at a depth where the concentrations of sulphate and methane reach their minimum values (Iversen and Jorgensen, 1985; Martens and Berner, 1977; Alperin et al., 1988). This correlation is in part due to the rapid consumption of sedimentary organic matter by sulphate reduction and early microbial production of methane during burial (Borowski et al., 1999). At the SMI, the archaea grow in dense aggregates of about 100 cells and are surrounded by sulphate-reducing bacteria (Boetius et al., 2000). These aggregates were abundant in gas-hydrate-rich sediments with extremely high rates of methane-based sulphate reduction, and apparently mediate anaerobic oxidation of methane (Boetius et al., 2000). Borowski et al. (1996) have shown that a substantial fraction of sulphate depletion is due to anaerobic methane oxidation driven by methane diffusing upward from depth. The SMI (Sulphate-Methane Interface) is shifted upward near the centre of a pockmark (Paull et al., 2002).

In the centre of the depression a correlation is observed between the high concentration of methane in the bottom water $(>20 \mu \mathrm{l} / \mathrm{l})$ and the area of the seafloor that was covered by carbonate mounds and beds of living mussels and tube worms. As previously evidenced by MacDonald et al. (1989) in the Gulf of Mexico, the mussels beds were sighted only in the centre of smaller depressions within the pockmark, associated with $4 \mathrm{~m}$ high carbonate domes. Higher fluxes were likely to have been occurring in the larger depressions where mussel's beds are located (Olu et al., 1996). The methane-dependant physiology of seep mussels (Childress et al., 1986) suggests that their fine-scale distribution within a seep site is determined by the availability of methane. The positive correlation between the abundance of mussels and the concentration of methane in the near-bottom water is consistent with this expectation. The strength of the correlation decreased with distance from the centre, which could indicate that discharges of the methane that nourished individual beds are discrete rather than pervasive. This would be consistent with the variability of methane concentrations in bottom-waters samples.

Furthermore, Methane hydrates have been found outcropping on the bottom above carbonate pavements. The main restriction for the occurrence of hydrates is the presence/supply of sufficient amounts of stabilizing gas molecules (Hyndman et al., 1992; Rempel et al., 1998). As outlined by Egorov et al. (1999), the steady-state model for gas hydrates on the seafloor requires a methane flux from below to compensate for its diffusive dissipation into the water. Gas hydrates outcropping on the seafloor is consistent with a high methane flux escaping in the centre of the depression.

In the similar vein, the fine-scale distribution of clams Vesicomydia should be controlled by the source of reduced sulfur compounds (Brooks et al., 1987). The clams are observed mainly in soft sediment and can survive on sulphide accumulations where fluid discharges are either or relict, as described at the outer border of the Giant Pockmark. Although the mussels are sometimes observed occurring on soft sediments, they occur far more frequently in association with carbonate outcrops, as in the centre of the depression. This could be due to active methane seepage localized along discontinuities. Reduction of $\mathrm{SO}_{4}{ }^{2-}$ to $\mathrm{H}_{2} \mathrm{~S}$ associated with oxidation of methane near the bottom surface proved to be essential process for benthic sulphide-dependant organisms (Larkin et al., 1994; MacDonald et al., 1989). Furthermore, methane hydrates have been recovered at $6 \mathrm{~m}$ and below in the core C-3, suggesting that the supply of methane is not sufficient to form hydrate at the bottom. This is consistent with the idea that all methane migrating upward is consumed at the SMI and does not reach the seafloor.

We propose here an evolutive model of morphological, chemical and biological features within a Giant Pockmark (Fig. 9), in which the centre is dominated by methane processes leading to methane-derived authigenic carbonates buildups and to the development of methane-dependant bacteria and endemic fauna, while the periphery is dominated by sulphide-dependent processes leading to the development of clams Vesicomyidia-type fauna living on black reduced sediments and white 
bacterial mats. Thus, sulphate reduction is clearly fuelled by high methane fluxes from below (Paull et al., 2002), while organic deposition from surface waters is not a significant substrate source for sulphate-reducing bacteria (SRB) (Boetius et al., 2000). Methane hydrates can only outcrop at the bottom 1) in the centre of a pockmark and 2) if the upward flux of methane is enough to get through the sulphate-reduction domain. This can be confirmed by the observation that high velocity vent sites are colonized only by methanotrophic mussels (Aharon, 1994), in the centre of a pockmark if the methane flux is strong, while vesicomyids occur in areas of low seepages or at the outer border of a pockmark. Finally, methane-dependant and sulphide-dependant patterns are concentrically organized at the bottom of the Giant Pockmark.

Figure 9: Evolutive model of morphological, chemical and biological features within a pockmark. The centre is dominated by methane-derived authigenic carbonates buildups and endemic bacteria and fauna. The periphery is dominated by sulphide-dependent Vesicomyidia-type fauna living on black reduced sediments and white bacterial mats. In this model the upper boundary of methane hydrates is concordant with the Sulphate-Methane Interface (SMI): the hydrates can only outcrop in the centre of a pockmark if the upward methane flux is sufficient.

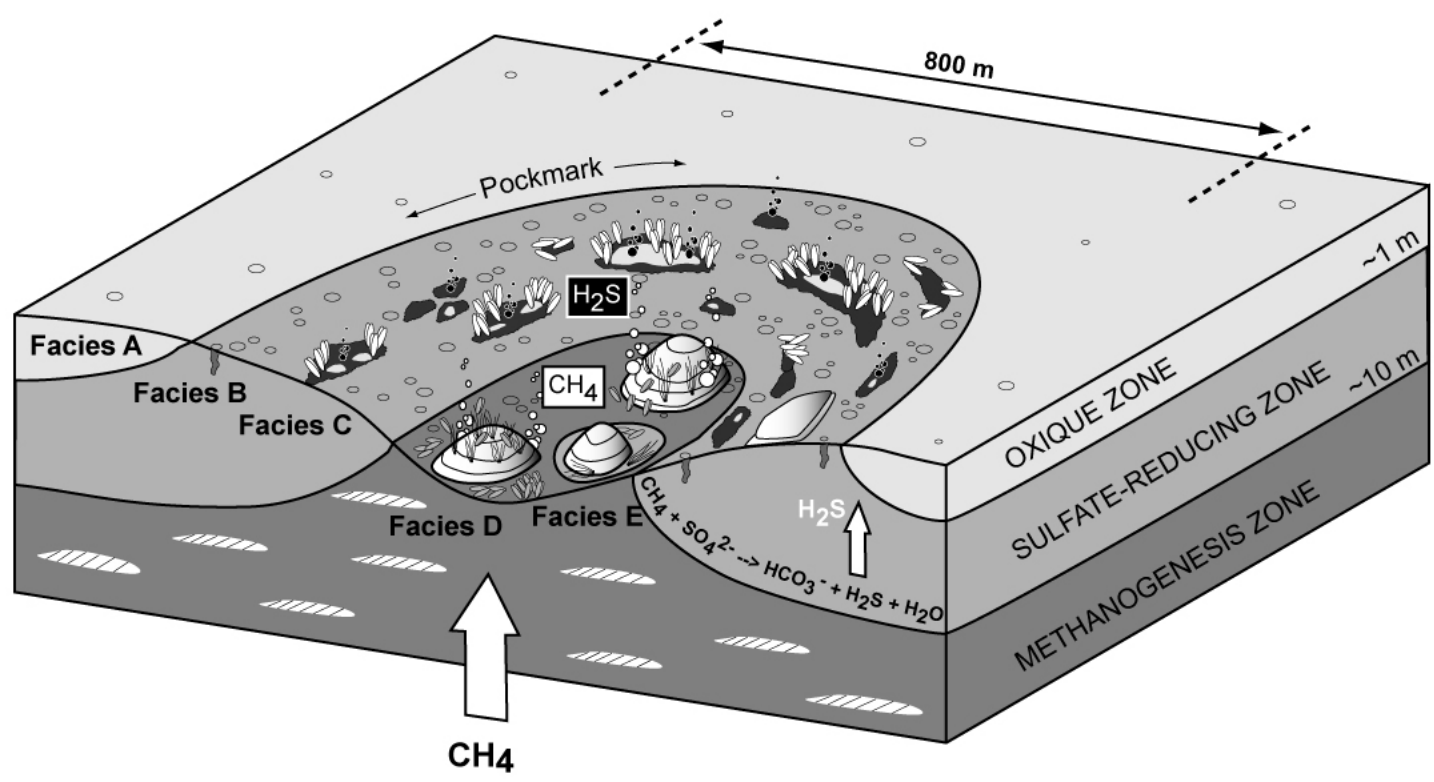

\begin{tabular}{|lll|}
\hline$\infty$ & Reduced black sediments with/without bacteria & \\
0 & Mussels (Mytilidea) living/dead & Burrows \\
& Clams (Vesicomyidea) living/dead & $\vdots$ Fluid seep $\left(\mathrm{CH}_{4}, \mathrm{H}_{2} \mathrm{~S}\right)$ \\
& Carbonate crusts/domes & \\
\hline
\end{tabular}

\section{Conclusion}

In the Lower Congo Basin, a $800 \mathrm{~m}$ wide Giant Pockmark exhibits a broad range of biological, mineralogical and chemical features on the seafloor, that are sulphide-related or methane-related. The flux of underlying methane supports microbial sulphate reduction leading to authigenic carbonate precipitation. A second product of 
the bacterially mediated sulphate reduction is hydrogen sulphide, partially trapped within the carbonate as pyrite, and partially mobilized into overlying sediment pore fluids to fuel the chemosynthesis of cold seep sulphide-dependant fauna. In this study, we have shown that:

1) The small coalescent depressions within the Giant Pockmarks harbor living or dead fauna, well or no developed carbonate buildup and high or low methane concentration in bottom waters, suggesting that the vent moves around laterally or that the fluid leakage is episodic.

2) Sedimentary facies at the bottom are concentrically arranged, with methanedependant features in the centre of the pockmark and sulphide-dependant features at the periphery of the depression. However, shallow fractures or discrete faults, maybe due to the collapse of the seep area, may drive fluids at the periphery of the pockmark allowing that methane escapes in the sulfide area.

3) The highest concentrations of methane (up to $20 \mu \mathrm{Mol} / \mathrm{l}$ ) in the bottom waters have been measured near the centre of the Giant Pockmark suggesting that the centre-zone may be the methane leak point.

4) Methane hydrates can outcrop at the bottom only in the centre of the pockmark if the upward flux of methane is enough to get through the sulphate-reduction domain.

Patchy and ephemeral occurrence of chemosynthetic fauna in areas of venting or seepage has been widely attributed to spatial and temporal variations in the supply of chemical nutrients (Suess et al., 1985; MacDonald et al., 1990; Beauchamp et al., 1992; Borowski et al., 1999). In this case, based on a multidisciplinary study of a Giant Pockmark in the Lower Congo Basin, we have shown that seafloor features at the bottom might be linked to the intensity of methane migrating from deeper levels.

Quantifying the contribution of fluid seeps to the ecology of the continental slope will be difficult; the true extent of fluid seepage is not well defined and the processes for upward and/or lateral fluid migration are unclear, but this study contribute to the understanding of the link between different spatial patterns of seafloor seeps and the progressive mixing of methane migrating from underlying levels.

\section{Acknowledgements}

We gratefully acknowledge IFREMER and TOTAL for their financial support and data supplies during the ZAIANGO project (1998-2000). We wish to thank the professionalism of the personnel of Genavir, who operated the submersible ROV Victor-6000 and its support ship Atalante. We (geologists) particularly appreciated the collaboration with biologists during BIOZAIRE survey, improving the knowledge of this topic and we would like to thank its kindly chief of mission, M. Sibuet.

\section{Bibliography}

Abrams, M.A., 1992. Geophysical and geochemical evidence for subsurface hydrocarbon leakage in the Bering Sea, Alaska. Marine and Petroleum Geology 9, 208-221.

Abrams, M.A., 1996. Distribution of subsurface hydrocarbon seepage in near-surface marine sediments. In: D. Schumacher, M.A. Abrams (Eds), Hydrocarbon Migration and its near-surface expression. AAPG Memoirs 66, pp. 1-14. 
Aharon, P., 1994. Geology and biology of modern and ancient submarine hydrocarbon seeps and vents. Geo-Marine Letters 14 (2/3), 69-73.

Aloisi, G., Bouloubassi, I., Heijs, S.K., Pancost, R.D., Pierre, C., Sinninghe Damste, J.S., Gottschal, J.C., Forney, L.J., Rouchy, J.-M., 2002. CH4-consuming microorganisms and the formation of carbonate crusts at cold seeps. Earth and Planetary Science Letters 203, 195-203.

Alperin, M.J., Reeburgh, W.S., Whiticar, M.J., 1988. Carbon and hydrogen isotope fractionation resulting from anaerobic methane oxidation. Global Biogeochemical Cycles 2, 279-288.

Baraza, J., Ercilla, G., Nelson, C.H., 1999. Potential geologic hazards on the eastern Gulf of Cadiz slope (SW Spain). Marine Geology 155, 191-215.

Beauchamp, B., Savard, M.M., 1992. Cretaceous chemosynthetic carbonate mounds in the Canadian Arctic. Palaios 7, 434-450.

Boe, R., Rise, L., Ottesen, D., 1998. Elongate depressions on the southern slope of the Nowegian trench (Skagerrak): morphology and evolution. Marine Geology 146, 191-203.

Boetius, A., Ravenschlag, K., Schubert, C.J., Rickert, D., Widdel, F., Gieske, A., Amann, R., Jorgensen, B.B., Witte, U., Pfannkuche, O., 2000. A marine microbial consortium apparently mediating anaerobic oxidation of methane. Nature 407, 623-626.

Borowski, W.S., Paull, C.K., Ussler III, W., 1999. Global and local variations of interstitial sulfate gradients in deep-water, continental margin sediments: sensivity to underlying methane and gas hydrates. Marine Geology 159, 131-154.

Borowski, W.S., Paull, C.K., Ussler III, W., 1996. Marine pore-water sulfate profiles indicate in situ methane flux from underlying gas hydrate. Geology 24 (7), 655658.

Brice, S.E., Cochran, M.D., Pardo, G., Edwards, A.D., 1982. Tectonics and Sedimentation of the South Atlantic Rift Sequence: Cabinda, Angola. In: Watkins and Drake (Eds.), Studies in Continental Margin Geology. AAPG Memoirs 34, pp. 5-18.

Brooks, J.M., Kennicutt II, M.C., Fisher, C.R., Macko, S.A., Cole, K., Childress, J.J., Bidigare, R.R., Vetter, R.D., 1987. Deep-sea hydrocarbon seep communities: Evidence for energy and nutritional carbon sources. Science 238, 11381142.

Brown, A., 2000. Evaluation of possible gas microseepage mechanisms. AAPG Bulletin 84 (11), 1775-1789.

Charlou, J.-L., Donval, J.-P., 1993. Hydrothermal methane venting between $12^{\circ} \mathrm{N}$ and $26^{\circ} \mathrm{N}$ along the Mid-Atlantic Ridge. Journal of Geophysical Research 98, 9625-9642.

Charlou, J.L., Donval, J.-P., Fouquet, Y., Ondréas, H., Cochonat, P., Levaché, D., Poirier, Y., Jean-Baptiste, P., Fourré, E., the ZAIROV-Leg 2 scientific party, 2004. Gas hydrates in the Congo-Angola Basin. Physical and Geochemical characteristics. Chemical Geology 205 (3-4), 405-425.

Childress, J.J., Fisher, C.R., Brooks, J.M., Kennicutt II, M.C., Bidigare, R.R., Anderson, A., 1986. A methanotrophic molluscan (Bivalvia: Mytilidae) symbiosis: mussels fueled by gas. Science 233, 1306-1308.

Claypool, G.E., Kaplan, I.R., 1974. The origin and distribution of methane in marine sediments. In: Kaplan, I.R. (Ed.), Natural Gases in Marine Sediments. Plenum Press, New York, pp. 99-139.

Cooper, C.K., 1999. Ocean currents offshore Northern Angola, Offshore Technology Conference 10749, Houston, Texas (3-6 May).

Dando, P.R., Austen, M.C., Burke, R.A., Kendall, M.A., Kennicutt II, M.C., Judd, A.G., Moore, D.C., Schmaljohann, R., Southward, A.J., 1991. Ecology of a North Sea pockmark with an active methane seep. Marine Ecology Progress Series 70, 4963.

Diaz del Rio, V., Somoza, L., Martinez-Frias, J., Mata, M.P., Delgado, A., Hernandez-Molina, F.J., Lunar, R., Martin, -.R., J.A., Maestro, A., Fernandez-Puga, 
M.C., Leon, R., Llave, E., Medialdea, T., Vazquez, J.T., 2003. Vast fields of hydrocarbon-derived carbonate chimneys related to the accretionary wedge/olistostrome of the Gulf of Cadiz. Marine Geology 195, 177-200.

Droz, L., Rigaut, F., Cochonat, P., Tofani, R., 1996. Morphology and recent evolution of the Zaire turbidite system (Gulf of Guinea). GSA Bulletin 108 (3), 253-269.

Egorov, A.V., Crane, K., Vogt, P.R., Rozhkov, A.N., 1999. Gas hydrate that outcrop on the sea floor: stability models. Geo-Marine Letters 19, 68-75.

Eichhubl, P., Greene, H.G., Naehr, T., Maher, N., 2000. Structural control of fluid flow: offshore fluid seepage in the Santa Barbara Basin, California. Journal of Geochemical Exploration 69/70, 545-549.

Fenchel, T., Blackburn, T.H., 1979. Bacteria and Mineral Cycling. Academic Press, New York, $225 \mathrm{p}$.

Gay, A., Lopez, M., Cochonat, P., Sultan, N., Cauquil, E., Brigaud, F., 2003. Sinuous pockmark belt as indicator of a shallow buried turbiditic channel on the lower slope of the Congo Basin, West African Margin. In: Van Rensbergen, P., R.R. Hillis, A.J. Maltman, Morley, C.K. (Eds.), Subsurface Sediment Mobilization. Geological Society of London Special Publications 216, pp. 173-189.

Giraudeau, J., Christensen, B.A., Hermelin, O., Lange, C.B., Motoyama, I., Shipboard Scientific Party, 1998. Biostratigraphic age models and sedimentation rates along the southwest African Margin. In: Wefer, G, W.H. Berger, C. Richter (Eds.), Proceedings of the Ocean Drilling Program, Initial Reports 175, pp. 543-546.

Greinert, J., Bollwerk, S.M., Derkachev, A., Bohrmann, G., Suess, E., 2002. Massive barite deposits and carbonate mineralization in the Derugin Basin, Sea of Okhotsk: precipitation processes at cold seep sites. Earth and Planetary Science Letters 203, 165-180.

Hecker, B., 1985. Fauna from a cold-sulfur-seep in the Gulf of Mexico: Comparison with hydrothermal vent communities and evolutionary implications. Biology Society of Washington Bulletin 6, 465-473.

Heggland, R., 1998. Gas seepage as an indicator of deeper prospective reservoirs. A study based on exploration 3D seismic data. Marine and Petroleum Geology 15, 1-9.

Hempel, P., Spiess, V., Schreiber, R., 1994. Expulsion of shallow gas in the Skagerrak- Evidence from subbottom profiling, seismic, hydroacoustical and geochemical data. Estuarine, Coastal and Shelf Science 38, 583-601.

Hovland, M., 1984. Gas induced erosion features in the North Sea. Earth Surface Processes and Landforms 9, 209-228.

Hovland, M., Talbot, M., Olaussen, S., Aasberg, L., 1985. Recently formed methane-derived carbonates from the North Sea floor. In: Thomas, B.M. (Ed.) Petroleum Geochemistry in Exploration of the Norwegian Shelf. Norwegian Petroleum Society, Graham \& Trotman, pp. 263-266.

Hovland, M., Judd, A., 1988. Seabed pockmarks and seepages. Impact on Geology, Biology and Marine Environment. Graham \& Trotman, London, 293 pp.

Hovland, M., 2002. On the self sealing nature of marine seeps. Continental Shelf Research 22 (16), 2387-2394.

Hyndman, R.D., Davis, E.E., 1992. A mechanism for the formation of methane hydrate and seafloor bottom-simulating reflectors by vertical fluid expulsion. JGR 97 (B5), 7025-7041.

Iversen, N., Jorgensen, B.B., 1985. Anaerobic methane oxidation rates at the sulfate-methane transition in marine sediments from Kattegat and Skagerrak (Denmark). Limnology and Oceanography 30, 944-955.

Jansen, J.H.F., Giresse, P., Moguedet, G., 1984. Structural and sedimentary geology of the Congo and southern Gabon continental shelf; a seismic and acoustic reflection survey. Netherlands Journal of Sea Research 17 (2-4), 364384.

Jollivet, D., Faugeres, J.C., Griboulard, R., Desbruyeres, D., Blanc, G., 1990. Composition and spatial organization of a cold seep community on the South 
Barbados accretionary prism: Tectonic, geochemical and sedimentary record. Progress in Oceanography 24, 25-45.

Jorgensen, N.O., 1992. Methane-derived carbonate cementation of Holocene marine sediments from Kattegat, Denmark: Geochemical and geological evidence. Marine Geology 103, 1-13.

Josenhans, H.W., King, L.H., Fader, G.B., 1978. A side-scan sonar mosaic of pockmarks on the Scotian shelf. Canadian Journal of Earth Sciences 15, 831-840.

Kelley, J.T., Dickson, S.M., Belknap, D.F., Barnhardt, W.A., Henderson, M., 1994. Giant sea-bed pockmarks: evidence for gas escape from Belfast Bay, Maine. Geology 22, 59-62.

Kennicutt II, M.C., Brooks, J.M., Bidigare, R.R., Fay, R.R., Wade, T.L., MacDonald, T.J., 1985. Vent-type taxa in a hydrocarbon seep region on the Louisiana slope. Nature 317, 351-353.

King, L.H., MacLean, B., 1970. Pockmarks on the Scotian shelf. Geological Society of America Bulletin 81, 3141-3148.

Kulm, L.D., Suess, E., Moore, J.C., Carson, B., Lewis, B.T., Ritger, S.D., Kadko, D.C., Thornburg, T.M., Embley, R.W., Rugh, W.D., Massoth, G.J., Langseth, M.G., Cochrane, G.R., Scamman, R.L., 1986. Oregon subduction zone: Venting fauna and carbonates. Science 231, 561-566.

Kvenvolden, K.A., Ginsburg, G.D., Soloviev, V.A., 1993. Worldwide distribution of subaquatic gas hydrates. Geo-Marine Letters 13, 32-40.

Larkin, J., Aharon, P., Henk, M.C., 1994. Beggiatoa in microbial mats at hydrocarbon vents in the Gulf of Mexico and warm mineral springs, Florida. GeoMarine Letters 14 (2/3), 97-103.

Laubier, L., Ohta, S., Sibuet, M., 1986. Découverte de communautés animales profondes durant la campagne franco-japonaise KAIKO de plongées dans les fosses de subduction autour du Japon. Comptes Rendus de l'Académie des Sciences de Paris 303 (III), 25-29.

LeMoigne, M., 1999. Compréhension des mécanismes de formation des pockmarks sur la pente du Golfe de Guinée. DEA "Géologie, Géophysique et Géochimie Sédimentaire". Université de Lille 1.

MacDonald, I.R., Boland, G.S., Baker, J.S., Brooks, J.M., Kennicutt.II, M.C. Bidigare, R.R., 1989. Gulf of Mexico hydrocarbon seep communities II. Spatial distribution of seep organisms and hydrocarbons at Bush Hill. Marine Biology 101, 235247.

MacDonald, I.R., Callender, W.R., Burke, R.A., MacDonald, S.J., Carney, R.S., 1990. Fine scale distribution of methanotrophic mussels at a Louisiana cold seep. Progress in Oceanography 24, 15-24.

Martens, C.S., Berner, R.A., 1977. Interstitial water chemistry of anoxic Long Island Sound sediments. I. Dissolved gases. Limnology and Oceanography 22, 10-25.

Martens, E.S., Berner, R.H., 1974. Methane production in the interstitial waters at sulfate-depleted marine sediments. Science 185, 1167-1169.

Marton, L.G., Tari, G.C., Lehmann, C.T., 2000. Evolution of the Angola passive Margin, West Africa, with Emphasis on Post-Salt Structural Styles. In: Moriak, W., M. Talwani (Eds.), Atlantic Rifts and Continental Margins. American Geophysical Union, Washington DC, pp. 129-149.

Milkov, A., Vogt, P., Cherkashev, G., Ginsburg, G., Chernova, N., Andriashev, A., 1999. Sea-floor terrains of Hakon Mosby Mud Volcano as surveyed by deep-tow video and still photography. Geo-Marine Letters 19, 38-47.

Olu, K., Lance, S., Sibuet, M., Henry, P., Fiala-Medioni, A., Dinet, A., 1997. Cold seep communities as indicators of fluid expulsion patterns through mud volcanoes seaward of the Barbados accretionary prism. Deep-Sea Research 44 (5), 811-841.

Olu, K., Sibuet, M., Harmegnies, F., Foucher, J.-P., Fiala-Medioni, A., 1996. Spatial distribution of diverse cold seep communities living on various diapiric structures of the southern Barbados prism. Progress in Oceanography 38, 347-376. 
Olu-Le Roy, K., Nadalig, T., Caprais, J.C., Fifis, A., Fabri, M.-C., Ondréas, H., Sibuet, M., 2003. Spatial variability of the chemosynthetic fauna, chemical environment and microbial communities on a giant pockmark in the Gulf of Guinea, 10th Deep-Sea Biology Symposium, Oregon Coast, U.S.A.

Ondreas, H., Charlou, J.L., Olu, K., Fouquet, Y., Cochonat, P., Gay, A., Dennielou, B., Donval, J.P., Fifis, A., Nadalig, T., Sibuet, M., 2005. Integrated "in situ" study of a deep giant pockmark on the Congo-Angola margin. Geo-Marine Letters, In Press.

Orange, D.L., Yun, J., Maher, N., Barry, J., Greene, G., 2002. Tracking California seafloor seeps with bathymetry, backscatter and ROVs. Continental Shelf Research 22 (16), 2273-2290.

Paull, C., Ussler III, W., Maher, N., Greene, H.G., Rehder, G., Lorenson, T., Lee, H., 2002. Pockmarks off Big Sur, California. Marine Geology 181 (4), 323-335.

Paull, C.K., Hecker, B., Commeau, R.S., Freeman-Lynde, R.P., Neumann, C., Corso, W.P., Golubic, S., Hook, J.E., Sikes, E., Curray, J., 1984. Biological communities at the Florida escarpment resemble hydrothermal vent taxa. Science 226, 965-967.

Rempel, A.W., Buffet, B.A., 1998. Mathematical models of gas hydrate accumulation. In: Henriet, J-P., J. Mienert (Eds.), Gas Hydrates: Relevance to World Margins Stability and Climatic Change. Geological Society of London, Special Publications 137, pp. 63-74.

Ritger, S.D., Carson, B., Suess, E., 1987. Methane-derived authigenic carbonates formed by subduction-induced pore water expulsion along the Oregon/Washington margin. GSA bulletin 98, 147-156.

Roberts, H.H., Aharon, P., 1994. Hydrocarbon-derived carbonate buidups of the northern Gulf of Mexico continental slope: a review of submersible investigations. Geo-Marine Letters 14 (1/2), 135-148.

Sassen, R., Losh, S.L., Cathles III, L., Roberts, H.H., Whelan, J.K., Milkov, A.V., Sweet, S.T., DeFreitas, D.A., 2001. Massive vein-filling gas hydrate: relation to ongoing gas migration from the deep subsurface in the Gulf of Mexico. Marine and Petroleum Geology 18, 551-560.

Sassen, R., MacDonald, I.R., Requejo, A.G., Guinasso Jr, N.L., Kennicutt II, M.C., Sweet, S.T., Brooks, J.M., 1994. Organic geochemistry of sediments from chemosynthetic communities, Gulf of Mexico slope. Geo-Marine Letters 14, 110-119.

Savoye, B., Cochonat, P., Apprioual, R., Bain, O., Baltzer, A., Bellec, V., Beuzart, P., Bourillet, J.-F., Cagna, R., Cremer, M., Crusson, A., Dennielou, B., Diebler, D., Droz, L., Ennes, J.-C., Floch, G., Guiomar, M., Harmegnies, F., Kerbrat, R., Klein, B., Kuhn, H., Landuré, J.-Y., Lasnier, C., Le Drezen, E., Le Formal, J.-P., Lopez, M., Loubrieu, B., Marsset, T., Migeon, S., Normand, A., Nouzé, H., Ondréas, H., Pelleau, P., Saget, P., Séranne, M., Sibuet, J.-C., Tofani, R., Voisset, M., 2000. Structure et évolution récente de l'éventail turbiditique du Zaire: premier résultats scientifiques des missions d'exploration Zaiango 1 et 2 (Marge Congo-Angola). Comptes-Rendus de l'Académie des Sciences de la Terre et des Planètes 331, 211-220.

Séranne, M., 1999. Early Oligocene stratigraphic turnover on the west Africa continental margin: a signature of the Tertiary greenhouse-to-icehouse transition ? Terra Nova, 11, 135-140.

Séranne, M., Seguret, M., Fauchier, M., 1992. Seismic super-units and post-rift evolution of the continental passive margin of southern Gabon. Bulletin de la Société Géologique de France 163 (2), 135-146.

Shaw, J., Courtney, R.C., Currie, J.R., 1997. Marine geology of St. George's Bay, Newfoundland, as interpreted from multibeam bathymetry and backscatter data. Geo-Marine Letters 17, 188-194.

Sibuet, M., Olu, K., 1998. Biogeography, biodiversity and fluid dependence of deep-sea cold-seep communities at active and passive margins. Deep-Sea Research II 45, 517-567. 
Sills, G.C., Wheeler, S.J., 1992. The significance of gas for offshore operations. Continental Shelf Research 12 (10), 1239-1250.

Sloan, E.D., 1990. Clathrate Hydrates of Natural Gases. Marcel Dekker, New York.

Solheim, A., Elverhoi, A., 1993. Gas-related sea floor craters in the Barents Sea. Geo-Marine Letters 13, 235-243.

Soter, S., 1999. Macroscopic seismic anomalies and submarine pockmarks in the Corinth-Patras rift, Greece. Tectonophysics 308, 275-290.

Stakes, D.S., Orange, D., Paduan, J.B., Salamy, K.A., Maher, N., 1999. Cold-seeps and authigenic carbonate formation in Monterey Bay, California. Marine Geology 159, 93-109.

Suess, E., Carson, B., Ritger, S.D., Moore, J.C., Jones, M.L., Kulm, L.D., Cochrane, G.D., 1985. Biological communities at vent sites along the subduction zone off Oregon. Biological Society of Washington Bulletin 6, 475-484.

Suess, E., Torres, M.E., Bohrmann, G., Collier, R.W., Greinert, J., Linke, P., Rehder, G., Trehu, A., Wallmann, K., Winckler, G., Zuleger, E., 1999. Gas hydrate destabilization: enhanced dewatering, benthic material turnover and large methane plumes at the Cascadia convergent margin. Earth and Planetary Science Letters 170 (1/2), 1-15.

Taylor, M.H., Dillon, W.P., Pecher, I.A., 2000. Trapping and migration of methane associated with the gas hydrate stability zone at the Blake Ridge Diapir: new insights from seismic data. Marine Geology 164, 79-89.

Uchupi, E., 1992. Angola Basin: Geohistory and Construction of the Continental Rise. In: Poag, C.W., P.A. De Graciansky (Eds.), Geologic Evolution of Atlantic Continental Rifts. Nostrand Reinhold, New York, pp. 77-99.

Valle, P.J., Gjelberg, J.G., Helland-Hansen, W., 2001. Tectonostratigraphic development in the eastern Lower Congo Basin, offshore Angola, West Africa. Marine and Petroleum Geology 18, 909-927.

Vogt, P.R., Gardner, J., Krane, K., 1999a. The Norwegian-BarentsSvalbard (NBS) continental margin: Introducing a natural laboratory of mass wasting, hydrates, and ascent of sediment, pore water, and methane. Geo-Marine Letters 19, 221.

Vogt, P.R., Gerdner, J., Crane, K., Sundvor, E., Bowles, F., Cherkashev, G., 1999b. Ground-truthing 11- to $12-\mathrm{kHz}$ side-scan sonar imagery in the NorwegianGreenland Sea. Part I: Pockmarks on the Vestnesa Ridge and Storegga slide margin. Geo-Marine Letters 19, 97-110.

Von Rad, U., Rosch, H., Berner, U., Geyh, M., Marchig, V., Schulz, H., 1996. Authigenic carbonates derived from oxidized methane vented from the Makran accretionary prism off Pakistan. Marine Geology 136, 55-77.

Wefer, G., Berger, W.H., Richter, C., 1998. Facies patterns and authigenic minerals of upwelling deposits off Southwest Africa. In: Wefer, G. W.H. Berger, C. Richter (Eds.), Proceedings of the Ocean Drilling Program, Initial Reports 175, pp. 487504.

Wenger, L.M., Isaksen, G.H., 2002. Control of hydrocarbon seepage intensity on level of biodegradation in sea bottom sediments. Organic Geochemistry 33 (12), 1277-1292.

Werner, F., 1978. Depressions in mud sediments (Eckernfoerde Bay, Baltic Sea) related to sub-bottom and currents. Meyniana 30, 99-104.

Whiticar, M.J., Faber, E., 1986. Methane oxidation in sediment and water column environments-isotope evidence. In: Rullkötter, J. (Ed.), Advances in Organic Geochemistry, pp. 759-768.

Whiticar, M.J., Werner, F., 1981. Pockmarks : Submarine vents of natural gas or freshwater seeps ? Geo-Marine Letters 1, 193-199.

Yuan, F., Bennel, J.D., Davis, A.M., 1992. Acoustic and physical characteristics of gassy sediments in the western Irish Sea. Continental Shelf Research 12 (10), 1121-1134. 
A.Gay et al - Seafloor features related to methane flux within a pockmark

Yun, J.W., Orange, D.L., Field, M.E., 1999. Subsurface gas offshore of northern California and its link to submarine geomorphology. Marine Geology 154, 357-368. 